\title{
Changes in lung function of granite crushers exposed to moderately high silica concentrations: a 12 year
} follow up

P Malmberg, H Hedenström, B-M Sundblad

\begin{abstract}
45 granite crushers and 45 age and smoking matched referents underwent pulmonary function tests in 1976 and 1988. On average, the granite crushers at follow up had worked for 22 years, were 52 (range 36-78) years old, and had inhaled a cumulated amount of $7 \mathrm{mg}$ of silica in the respirable dust fraction. Between 1976 and 1988 the average concentration of respirable quartz in air was $0.16 \mathrm{mg} / \mathrm{m}^{3}$ (threshold limit value $\left.(T L V)=0.10 \mathrm{mg} / \mathrm{m}^{3}\right)$. In 1988 the granite crushers had somewhat lower forced expiratory flows (forced expiratory volume in one second/vital capacity $\left(F E V_{1} /\right.$ VC) $-4 \cdot 5 \%$ and forced midexpiratory flow $\mathbf{F E F}_{50}$ $-15 \%)$ compared with the referents and a more uneven ventilation distribution $(17 \%$ higher slope of phase III in the nitrogen single breath curve). Five smoking granite crushers, but none of the referents, had an $\mathrm{FEV}_{1}<80 \%$ of the predicted. During the 12 year interval the granite crushers had-compared with the matched referents-a greater decrease in FEV $_{1}(-4 \cdot 6 \%)$, FEV $/$ VC $(-5 \cdot 4 \%)$, maximal expiratory flow, $(-8 \%)$ and FEF $_{50}(-14 \%)$, and a larger increase in phase III and static compliance $(p<0.02$ in all variables). The functional changes suggest the presence of airways obstruction and increased compliance of the lungs. Exposure to silica at concentrations of about twice the present TLV was thus associated with airways obstruction and loss of elastic recoil rather than fibrosis and a restrictive function loss as seen in silicosis. The changes were on average small, but in some tobacco smokers more pronounced changes were found.
\end{abstract}

(British fournal of Industrial Medicine 1993;50:726-731)

National Institute of Occupational Health, Solna, Sweden

P Malmberg, H Hedenström, B-M Sundblad
Inhalation of silica $\left(\mathrm{SiO}_{2}\right)$ in crystalline form is a well known cause of the pneumoconiosis, silicosis. The disease is characterised by granulomatous and fibrotic changes and emphysema in the lungs, and is believed to be caused by chronic stimulation of phagocytic cells such as macrophages and the subsequent release of inflammatory mediators. ${ }^{1}$ The silica particles are removed from the lungs at a very slow rate. Thus even if exposure is stopped the retained particles may continue to exert their effect and lung function may continue to deteriorate even after retirement. ${ }^{2}$ The process is slow and silicosis is usually found after the age of $50 .^{3}$ It is typically diagnosed by chest radiography, and is often accompanied by changes in restrictive lung function and a reduction in lung transfer factor (TLCO). The threshold limit value (TLV) has been $0.1 \mathrm{mg}$ respirable silica $/ \mathrm{m}^{3}$ of air in Sweden (and the United States) since 1978, and the number of new cases of silicosis reported each year in Sweden is low. Probably most of these cases have been caused by exposures occurring before 1978, in view of the long latency time before the disease becomes overt.

There is a poor correlation between changes in lung function and chest radiographic changes indicating silicosis. In highly exposed populations most workers seem to have obstructive airway changes even if only a minority show evidence of silicosis. ${ }^{4}$ In animal studies airway obstructive changes may be found before and independently of silicotic changes. ${ }^{56}$ Emphysema in subjects exposed to silica seems to be rather independent of silicosis. ${ }^{7}$ Silica and tobacco smoking may act additively or possibly synergistically in inducing obstructive changes in airways. ${ }^{8}$ Thus silica may cause obstructive pulmonary function changes at lower concentrations and possibly with shorter latency time than is required for the induction of silicosis.

In 1976 granite crushers were examined by extensive lung function tests. Most results were within normal limits, including forced expiratory flow in one second $\left(\mathrm{FEV}_{1}\right)$, but the closing volume was increased, which suggests peripheral airway changes. ${ }^{9}$ The present report concerns the results of a reinvestigation of these workers 12 years later together with a matched sample from the original 
Table 1 Lung function tests

\begin{tabular}{|c|c|c|}
\hline \multicolumn{3}{|c|}{ Abbreviation } \\
\hline TLC & (l) & Total lung capacity \\
\hline RV & (1) & Residual volume \\
\hline Gaw/V & $\left(\mathrm{kPa}^{-1} \mathrm{~s}^{-1}\right)$ & Specific airway conductance \\
\hline VC & (1) & Vital capacity \\
\hline $\mathrm{FEV}_{1}$ & (1) & $\begin{array}{l}\text { Forced expiratory volume in one } \\
\text { second }\end{array}$ \\
\hline $\mathrm{FEV}_{1} / \mathrm{VC}$ & $(\%)$ & \\
\hline MVV40 & $\left(1 \mathbf{s}^{-1}\right)$ & $\begin{array}{l}\text { Maximal voluntary ventilation } \\
\text { ( } 40 \text { breaths/ minute) }\end{array}$ \\
\hline MEF & $\left(1 \mathrm{~s}^{-1}\right)$ & Maximal expiratory flow \\
\hline $\mathrm{FEF}_{50}$ & $\left(1 \mathrm{~s}^{-1}\right)$ & Forced midexpiratory flow \\
\hline Phase III & & $\begin{array}{l}\text { Slope of the alveolar plateau } \\
\text { (nitrogen single breath test) }\end{array}$ \\
\hline $\begin{array}{l}\text { CV } \\
\text { CV/VC }\end{array}$ & $\begin{array}{l}(1) \\
(\%)\end{array}$ & Closing volume \\
\hline CC & $(1)$ & Closing capacity \\
\hline Pel(max) & (kPa) & Maximal elastic recoil pressure \\
\hline Cst & $\left(\mathrm{kPa}^{-1}\right)$ & $\begin{array}{l}\text { Static compliance. Volume change } \\
\text { per pressure } \\
\text { change between } 50-80 \% \text { of TLC }\end{array}$ \\
\hline TLCo & $\left(\mu \mathrm{mol} \mathrm{s}^{-1} \mathrm{kPa}^{-1}\right)$ & $\begin{array}{l}\text { Transfer factor (diffusion capacity } \\
\text { for carbon monoxide, single } \\
\text { breath test). }\end{array}$ \\
\hline
\end{tabular}

reference population. The aim was to investigate changes in lung function over this time, and to compare changes in lung function to exposure to silica dust, smoking, and chest radiographic evidence of silicosis.

\section{Material and methods}

Sixty two male granite crushers participated in the original study in 1976, together with 263 male referents invited from participants in a health survey in which about $70 \%$ of the male adult population in Uppsala, Sweden participated. Invitations were extended to the granite crushers and controls selected from the original reference population and matched for age and smoking. Thus for each granite crusher two or more referents with similar age and smoking habits (according to the 1976 investigation) were selected. The first on the list was invited and if he did not attend the investigation, the second was invited and so forth. Two referents, who in the 1988 survey were found to have pleural plaques, were excluded and replaced with two others.

\section{LUNG FUNCTION}

The granite crushers and the referents were investigated by the same technician and during the same periods in 1976 and 1988 at the Department of Clinical Physiology, University Hospital, Uppsala, Sweden. A chest radiograph was taken on both occasions and the participants were asked to complete a questionnaire on respiratory symptoms and smoking habits.

For some of the tests the same equipment was used in 1976 and 1988; for other tests the original equipment was no longer available. Table 1 gives a list of the abbreviations of the lung function measures. In 1976 and 1988 TLC and RV were measured in a constant volume plethysmograph (Siregnost FD91S = FD40, Siemens AG, Erlangen, Germany). Gaw/V was computed from airways resistance and thoracic gas volume (average of end inspiratory and end expiratory measurements). In 1976 VC and forced expiratory flows were measured with a CPI (Cardiopulmonary Instruments Corporation, Houston, Texas, USA) Pulmolab 5300, which included a dry rolling seal low resistance spirometer. The flows were calculated from curves recorded on an $x-y$ recorder. In 1988 a spirometer of the same type was used (Ohio 840, Airco medical products, Madison, Wis) connected to an on line computer with a locally produced program fulfilling the American Thoracic Society requirements. ${ }^{10}$ The $\mathrm{CV}$ and phase III were measured by a single breath nitrogen test with the CPI-pulmolab- equipment in 1976; in 1988 a computerised pneumotach based system was used (Hewlet Packard nitrogen analyser and flow meter 47302A $=47304 \mathrm{~A}$, Cupertino, $\mathrm{Cal}$ ). TLCo was measured by a single breath $\mathrm{CO}$ method with the CPI pulmolab in 1976 and a Transfer test equipment (PK Morgan Ltd, Chatham, Kent, UK) in 1988.

In 1976 and 1988 Cst and Pel(max) were measured with a latex balloon $(10 \mathrm{~cm}, 3.6 \mathrm{~cm}$ perimeter, thickness $0.06 \mathrm{~cm}$ ) placed in the lower third of the oesophagus. Expiratory flow was controlled at $0.51 \mathrm{~s}^{-1}$ and was automatically interrupted for $0.4 \mathrm{~s}$ every second. The curve displaying exhaled volume and pressure difference between mouth and oesophagus was displayed on an $x-y$ recorder. Cst was computed as the average slope of the interrupted points on the expiratory curve between 50 and $80 \%$ of TLC, assuming that the end of inspiration reached TLC.

The criteria for selecting representative values from multiple recordings were: TLC-average of three measurements of thoracic gas volume plus the best of two measurements of inspiratory capacity; RV-TLC minus the highest of two VCs measured in the body plethysmograph; VC-highest of three slow and three forced VC efforts performed with the spirometer; $\mathrm{FEV}_{1}$ - highest of three efforts; $\mathrm{FEV}_{1} / \mathrm{VC}$ - highest $\mathrm{FEV}_{1}$ divided by VC (defined above); MVV40 - highest from two efforts (best 10 seconds within a 15 second or more effort); MEFhighest value; and $\mathrm{FEF}_{50}$-average from three efforts with a forced vital capacity within $5 \%$ of the highest; $\mathrm{CV}$ - average from three efforts with a VC within $5 \%$ of the highest; CV/VC-CV divided by the highest VC recorded during the $\mathrm{CV}$ test; $\mathrm{CC}-$ TLC measured in the body plethysmograph minus the average value of three individual determinations of $\mathrm{VC}$ of the closing volume test minus $\mathrm{CV}$; 
Table 2 Age, height, weight, and work-years in granite crushers and matched referents

\begin{tabular}{|c|c|c|c|}
\hline & \multicolumn{2}{|l|}{ Granite crushers } & \multirow{2}{*}{$\begin{array}{l}\text { Referents } \\
(n=45) \\
\text { Mean (Range) }\end{array}$} \\
\hline & $\begin{array}{l}\text { all }(n=45) \\
\text { Mean (Range) }\end{array}$ & $\begin{array}{l}\text { active }(n=23) \\
\text { Mean (Range) }\end{array}$ & \\
\hline $\begin{array}{l}\text { Age }(\mathrm{y}) \\
\text { Height }(\mathrm{cm}) \\
\text { Weight }(\mathrm{kg}) \\
\text { Work-years }\end{array}$ & $\begin{array}{l}52 \cdot 4(35 \cdot 5-77 \cdot 8) \\
176(163-196) \\
79(56-105) \\
21 \cdot 7(4-40)\end{array}$ & $\begin{array}{l}50 \cdot 4(40-65) \\
176(166-186) \\
82(64-105) \\
26 \cdot 3(18-40)\end{array}$ & $\begin{array}{l}52 \cdot 1(31 \cdot 8-72 \cdot 7) \\
176(160-190) \\
77(60-97)\end{array}$ \\
\hline
\end{tabular}

Pel(max) - maximal value from at least two efforts; Cst-average from at least two efforts; and TLCothe first of two reproducible efforts (within $5 \%$ of highest). The details of the procedures have been described elsewhere. ${ }^{9}$ The TLCO was not measured in all subjects and some refused the measurement of lung mechanics (Table 6 lists missing values).

\section{EXPOSURE ASSESSMENT}

Dust exposure was assessed individually for each worker based on yearly gravimetric dust measurements with personal or stationary filter cassettes placed at different work stations. The inhaled amount of dusts was calculated from measured dust concentrations at different work sites, time spent at these work sites, and estimated ventilation. ${ }^{11}$ The total amount of inhaled dust, the amount in the respirable fraction, and the amount of silica in the respirable fraction were calculated for the periods up to 1976 and up to 1988 as were individual average concentrations of dust and silica in air for the period up to 1976 and for the period between 1976 and 1988.

\section{STATISTICAL EVALUATION}

Data were evaluated with the SAS-JMP statistical package on a Macintosh computer. In the comparison between granite crushers and referents in 1988, lung function values were expressed as \% of predicted from the reference equations derived from a normal population examined with the equipment used in 1976. ${ }^{12}{ }^{13}$ Some of the lung function variables measured in 1988 on the referent population deviated significantly from predicted values, possibly reflecting that the different equipment used for some tests in 1988 may have influenced the test results. Therefore, emphasis is placed on the difference between granite crushers and referents regarding change of lung function during the 12 years, rather than on the absolute change. A two sided Student's $t$ test was used, or in case of skewed distribution, the Wilcoxon's signed rank test (paired samples) or the Mann-Whitney $U$ test (unpaired samples). For some purposes multiple regression with the lung function test as dependent value was used.
Table 3 Smoking habits in granite crushers and referents in 1988

\begin{tabular}{llll}
\hline & Non-smokers & Ex-smokers & Smokers \\
\hline Stone crushers (all 45): & & & \\
No & 11 & 22 & 12 \\
Cigarettes per day & & $15(6)$ & $20(8)$ \\
Smoking-years & & $24(13)$ & $28(9)$ \\
Pack-years & & $17(8)$ & $26(11)$ \\
Stone crushers (23 active): & 6 & 12 & 5 \\
No & 6 & $15(4)$ & $16(5)$ \\
Cigarettes per day & & $23(11)$ & $31(11)$ \\
Smoking-years & & $17(8)$ & $22(4)$ \\
Pack-years & 13 & 16 & 16 \\
Referents (n=45): & & $16(6)$ & $13(7)$ \\
No & $28(12)$ & $22(11)$ \\
Cigarettes per day & & $16(11)$ & $19(12)$ \\
Smoking-years & &
\end{tabular}

${ }^{\star}$ Cigarettes per day $\times$ smoking-years/20 (cigarette-pack-years)

\section{Results}

STUDY GROUPS

Five of the 62 granite crushers investigated in 1976 refused to attend the investigation. Another six were considered too senile or too ill to participate (illness not related to lung disease). Six had died from causes other than lung disease, leaving 45 granite crushers that were re-examined in 1988. Two out of the 10 granite crushers who were born before 1918 ( $>70$ years of age in 1988) were examined. Thirty three per cent of those who were designated as referents were not reached or could not or would not participate in the follow up.

The average difference in age between matched referents and granite crushers was $0.3 \pm 2.4$ years, maximum \pm 6 years (NS). There were no significant differences in height or weight (table 2). There were small differences in smoking habits in 1988, as the matching was based on smoking habits in 1976 and the referents had changed smoking habits more than the granite crushers (table 3 ).

\section{EXPOSURE}

In 1988 the granite crushers had on average worked for 22 years and inhaled $136 \mathrm{mg}$ of granite dust with $7 \mathrm{mg}$ of silica in the respirable fraction. Twenty three had been working as granite crushers for the entire period between 1976 and 1988 (referred to as the active group). Thirty out of the 42 granite crushers who had been working for at least some years between 1976 and 1988 had been exposed to average dust concentrations in excess of the TLV value of $0.1 \mathrm{mg} / \mathrm{m}^{3}$ introduced in 1978 . During 1988 eight out of 23 had on average been exposed to dust concentrations above the TLV. Tables 4 and 5 give further details. The decrease in the concentration of total dust, respirable dust, and respirable silica from the period before 1976 to the period 1976-88 was statistically significant $(\mathrm{p}<0.01)$. 
Table 4 Dust exposure, all 45 granite crushers

\begin{tabular}{|c|c|c|c|c|c|c|}
\hline & 1976 & 1988 & Difference (\%) & Before 1976 & $1976-88$ & Difference (\%) \\
\hline $\begin{array}{l}\text { Cumulative amount ( } \mathrm{g} \\
\text { Total dust } \\
\text { Respirable dust } \\
\text { Respirable silica }\end{array}$ & $\begin{array}{l}105 \\
21 \\
4 \cdot 9\end{array}$ & $\begin{array}{l}136 \\
32 \\
7 \cdot 2\end{array}$ & $\begin{array}{l}(30) \\
(49) \\
(48)\end{array}$ & - & - & \\
\hline $\begin{array}{l}\text { Average concentration } \\
\text { Total dust } \\
\text { Respirable dust } \\
\text { Respirable dust } \\
\text { Silica in } \\
\quad \text { respirable dust (\%) }\end{array}$ & $\begin{array}{l}\left.g / m^{3}\right): \\
- \\
- \\
- \\
-\end{array}$ & $\begin{array}{l}- \\
- \\
-\end{array}$ & $\begin{array}{l}- \\
- \\
-\end{array}$ & $\begin{array}{l}4 \cdot 1 \\
0 \cdot 87 \\
0 \cdot 21 \\
25\end{array}$ & $\begin{array}{l}2 \cdot 6 \\
0 \cdot 83 \\
0 \cdot 18^{\star} \\
23\end{array}$ & $\begin{array}{l}(37) \\
(-4) \\
(-11) \\
(-6)\end{array}$ \\
\hline
\end{tabular}

$\star^{\star} \mathrm{n}=42$.

\section{CLINICAL FINDINGS AND LUNG FUNCTIONS}

Five granite crushers but none of the referents had $\mathrm{FEV}_{1}$ values less than $80 \%$ of predicted ( $\mathrm{p}<$ $0.05)$. All were smokers or ex-smokers. One 72 year old man had a severe reduction in lung function with a mixed restrictive and obstructive pattern and a reduction in TLCO compatible with silicosis but with a normal chest radiograph. The other four had an obstructive decrease in lung function with a normal TLCO. One granite crusher had chest radiographic changes suggestive of silicosis and a decrease in static compliance but a ventilatory capacity within normal limits. The rest had normal chest radiographs.

Positive replies to questions about symptoms in the questionnaires were more common among granite crushers than among referents (dyspnoea (granite crushers/referents) $6 / 1$, wheezing in the chest not related to cold or asthma $9 / 5$, chronic cough 10/7). The replies were graded according to severity and if the severity scores were taken into account (ordinal scale) the difference was significant for wheezing ( $p<0.02$ ), but only of borderline significance for dyspnoea $(p=0.09)$.

Table 6 shows the average lung function in granite crushers and referents in 1988. Compared with the matched referent population, the granite crushers had significantly lower $\mathrm{FEV}_{1} / \mathrm{VC}, \mathrm{FEF}_{50}$, and higher phase III (table 6).

The changes in lung function (expressed in \% of average absolute values of referent subjects) between 1976 and 1988 in granite crushers were compared with the change in referents (figure). During the 12 years $\mathrm{FEV}_{1}$ had decreased $4.6 \%$, $\mathrm{FEV}_{1} / \mathrm{VC}$ 5.4\%, MEF 8.0\%, and $\mathrm{FEF}_{50} 13 \cdot 7 \%$ more than in referents ( $p<0.01$ in all variables). The slope of the alveolar plateau had increased by $43 \%(p=0.02)$ and the static compliance had increased by $52 \%(\mathrm{p}<0.001)$. The granite crushers had on average a higher $\mathrm{CV}$ and CC (statistically non-signficant in 1988), but the referents had increased more in CV and CV/VC between 1976 and 1988 ( $p<0.02)$.

Active granite crushers tended to be younger than non-active workers (mean age $50 v 54$, NS) who were not exposed to silica during the entire follow up period, partly due to retirement. Active workers were less exposed (total silica $5.7 \mathrm{~g} v 8.6 \mathrm{~g}$, $\mathrm{p}<0.01$ ) and tended to have less lung function changes. Thus although only of borderline significance ( $p<0.1$ for each of the variables listed), the change (compared with referents) was less in active than in non-active granite crushers with regard to $\mathrm{FEV}_{1}, \mathrm{FEV}_{1} / \mathrm{VC}$, and phase III.

The change in lung function did not correlate significantly with the inhaled dose of respirable quartz in the granite crushers or with age or different smoking measures.

\section{Discussion}

The study was designed to investigate possible health effects of exposure to silica dust at concentrations close to the present TLV value. The measured exposure concentrations were on average

Table 5 Dust exposure, 23 active granite crushers *

\begin{tabular}{|c|c|c|c|c|c|c|}
\hline & 1976 & 1988 & Difference (\%) & Before 1976 & $1976-88$ & Difference (\%) \\
\hline $\begin{array}{l}\text { Cumulative aunount (g): } \\
\text { Total dust } \\
\text { Respirable dust } \\
\text { Respirable silica }\end{array}$ & $\begin{array}{l}114 \\
24 \\
5 \cdot 4\end{array}$ & $\begin{array}{l}155 \\
38 \\
8 \cdot 6\end{array}$ & $\begin{array}{l}(36) \\
(58) \\
(59)\end{array}$ & $\begin{array}{l}- \\
-\end{array}$ & $\begin{array}{l}- \\
-\end{array}$ & $\begin{array}{l}- \\
-\end{array}$ \\
\hline $\begin{array}{l}\text { Average concentration (mg/r } \\
\text { Total dust } \\
\text { Respirable dust } \\
\text { Respirable silica } \\
\text { \% Silica in respirable dust: }\end{array}$ & $\begin{array}{l}- \\
- \\
- \\
-\end{array}$ & $\begin{array}{l}- \\
- \\
-\end{array}$ & $\begin{array}{l}- \\
- \\
-\end{array}$ & $\begin{array}{l}4 \cdot 2 \\
0 \cdot 92 \\
0 \cdot 21 \\
24\end{array}$ & $\begin{array}{l}2 \cdot 1 \\
0 \cdot 68 \\
0 \cdot 16 \\
19\end{array}$ & $\begin{array}{l}(-51) \\
(-26) \\
(-25) \\
(-17)\end{array}$ \\
\hline
\end{tabular}

ॠGranite crushers who were exposed to silica all years $1976-88$. 
Table 6 Lung function of 45 granite crushers and 45 matched referents and difference in lung function between the groups in 1988

\begin{tabular}{|c|c|c|c|c|c|}
\hline \multirow[b]{3}{*}{ TLC } & \multirow{2}{*}{\multicolumn{2}{|c|}{$\frac{\text { Granite crushers }}{\text { Mean (SD) }}$}} & \multirow{2}{*}{\multicolumn{2}{|c|}{$\frac{\text { Referents }}{\text { Mean (SD) }}$}} & \multirow{3}{*}{$\begin{array}{l}\text { Difference } \\
\% \text { Significance } \\
2.5 \mathrm{NS}\end{array}$} \\
\hline & & & & & \\
\hline & $7 \cdot 47$ & $1 \cdot 10$ & $7 \cdot 38$ & 1.09 & \\
\hline $\mathbf{R V}$ & $2 \cdot 17$ & 0.71 & $2 \cdot 11$ & 0.77 & $4.8 \mathrm{NS}$ \\
\hline Gaw/V & $2 \cdot 19$ & $1 \cdot 31$ & 1.99 & $0 \cdot 83$ & $9 \cdot 4 \mathrm{NS}$ \\
\hline VC & $5 \cdot 20$ & 0.94 & $5 \cdot 24$ & $0 \cdot 82$ & $-0.1 \mathrm{NS}$ \\
\hline FEV1 & $3 \cdot 84$ & 0.91 & 3.99 & 0.73 & -3.4 NS \\
\hline FEV1/VC & $73 \cdot 0$ & $9 \cdot 45$ & $76 \cdot 2$ & $6 \cdot 55$ & $-4 \cdot 5^{\star \star}$ \\
\hline MVV40 & $2 \cdot 15$ & 0.49 & $2 \cdot 25$ & 0.39 & $-4 \cdot 4$ NS \\
\hline MEF & $9 \cdot 8$ & $2 \cdot 02$ & $10 \cdot 3$ & 1.69 & $-4.4 \mathrm{NS}$ \\
\hline FEF50 & $4 \cdot 52$ & $1 \cdot 82$ & $5 \cdot 1$ & $1 \cdot 52$ & $-14 \cdot 8^{\star}$ \\
\hline Phase III & 1.45 & 1.66 & $1 \cdot 1$ & 0.63 & $16 \cdot 9^{\star}$ \\
\hline $\mathrm{CV}$ & 1.00 & 0.30 & 0.94 & $0 \cdot 28$ & $6 \cdot 1 \mathrm{NS}$ \\
\hline CV/VC & 19.9 & $7 \cdot 14$ & $18 \cdot 2$ & $5 \cdot 54$ & $3.9 \mathrm{NS}$ \\
\hline CC & 3.60 & 0.84 & $3 \cdot 40$ & 0.96 & $6.7 \mathrm{NS}$ \\
\hline CC/TLC & $48 \cdot 2$ & $8 \cdot 86$ & $45 \cdot 7$ & $9 \cdot 31$ & $7 \cdot 3 \mathrm{NS}$ \\
\hline $\operatorname{Pel}(\max ) \ddagger$ & $2 \cdot 7 \overline{8}$ & 0.99 & $2 \cdot 81$ & 0.75 & -1.4 NS \\
\hline Cst & $4 \cdot 34$ & $1 \cdot 67$ & 4.03 & 1.66 & $12 \cdot 0 \mathrm{NS}$ \\
\hline TLCo & 177 & 38 & 173 & 32 & $3 \cdot 3 \mathrm{NS}$ \\
\hline
\end{tabular}

${ }^{\star} \mathrm{p}<0.05 ;{ }^{\star \star} \mathrm{p}<0.01$.

†Difference between lung function values of granite crushers and referents expressed in \% of predicted values.

拈ung mechanics (Pel(max), Cst); granite crushers $1976 \mathrm{n}=43$, $1988 \mathrm{n}=42$, referents $1976 \mathrm{n}=22,1988 \mathrm{n}=34$. Matched paired differences $1988-1976 \mathrm{n}=16$.

STransfer test; granite crushers $1976 n=33,1988 n=44$, referents $1976 n=21,1988 n=43$. Matched paired differences $1988-1976 \mathrm{n}=11$.

clearly higher, and even if a significant reduction was noted during the past 10 years, the average exposure was closer to twice the present TLV of $0.1 \mathrm{mg}$ respirable silica $/ \mathrm{m}^{3}$. If the group of active granite crushers only was considered, they had on average about $60 \%$ of their lifetime exposure before 1976, which suggests that most of the exposure occurred at concentrations closer to $0 \cdot 2$ than to $0 \cdot 1$ $\mathrm{mg} / \mathrm{m}^{3}$. The changes in lung function were moderate and the active group tended to have smaller changes in lung function than the retired granite crushers. The average change in $\mathrm{FEV}_{1}$ over the 12 years of observation was $3 \cdot 2 \%$ (of the average value in referents) greater than the change in referents, which can be compared with the normal variability within a healthy population of about $20 \%$. On the other hand, the changes were highly significant and consistent, suggesting airway obstruction, uneven gas distribution, and decrease in elastic recoil. Five granite crushers and none of the referents had an $\mathrm{FEV}_{1}$ less than $80 \%$ of predicted and the granite crushers tended to report symptoms of dyspnoea and wheeze more often than referents.

Two of the most heavily exposed granite crushers showed evidence of silicosis (one from changes in lung function, one from changes in his chest radiograph). In the other granite crushers, the changes in pulmonary function did not suggest classical silicosis. Thus the transfer test was on average normal, there was no evidence of restrictive

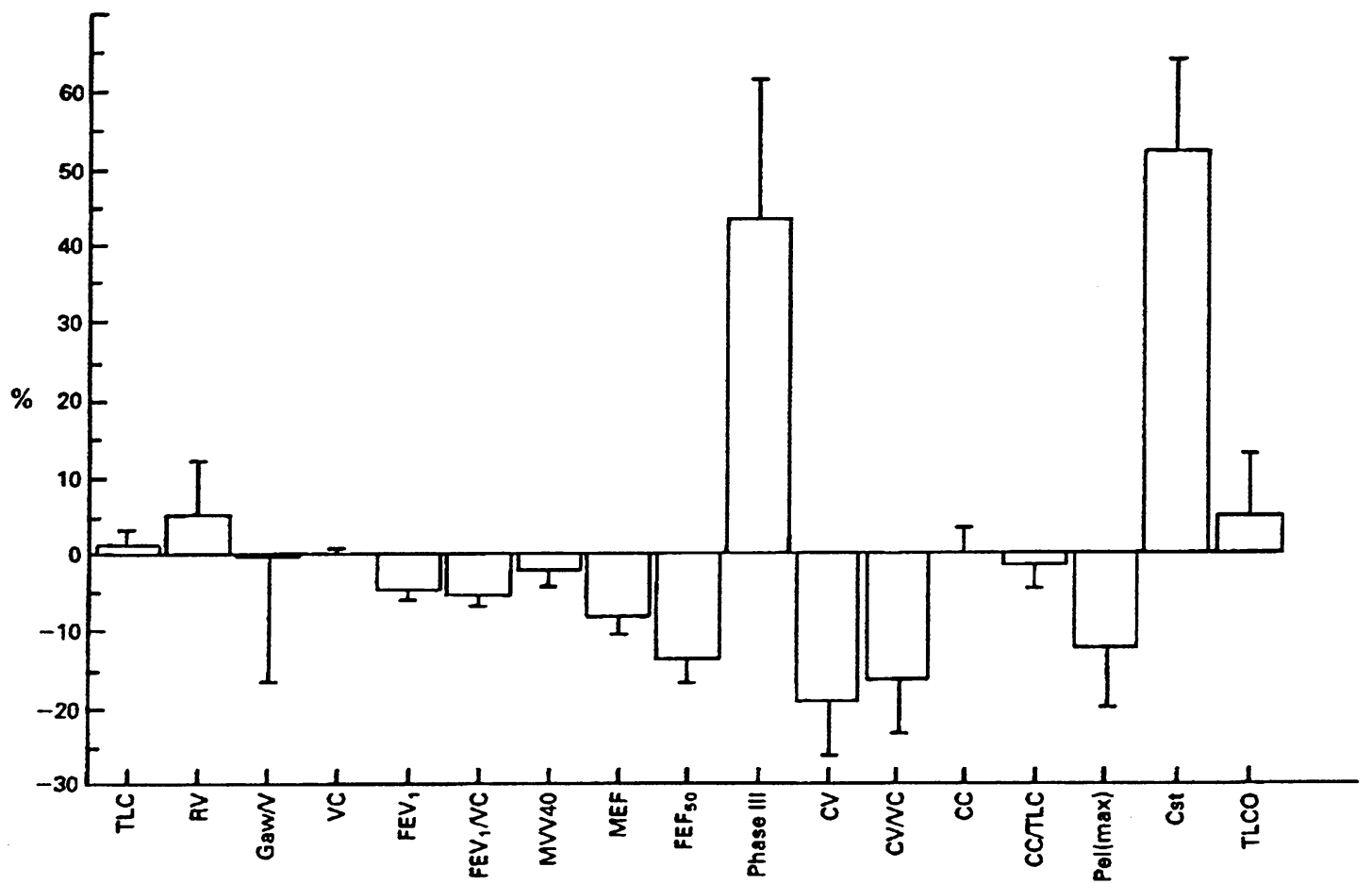

Changes in lung function between 1976 and 1988. The difference in amount of change between granite crushers and referents is expressed in \% of the average values for referents measured in both 1976 and 1988. 
lung function changes, and the mechanical investigations suggested emphysematous rather than fibrotic changes. These findings are consistent with other findings implying that airway obstructive changes may occur independently and precede silicosis. Because four of the cases with a clinically relevant reduction in $\mathrm{FEV}_{1}$ had a fairly low exposure to silica and all five were tobacco smokers or exsmokers, the findings are compatible with a hypothesis that obstructive changes in airways may occur at lower exposures than required for the development of silicosis and that interaction with tobacco smoke may aggravate the changes. The study group was, however, too small to confirm such assertions.

The decrease in lung function over the 12 year period seemed to be more pronounced in the group who had not been exposed to silica dust for the entire period (in some due to retirement for reasons of age, in others due to change in job). It is, however, possible that the changes in lung function in retired workers are due to retained silica, and that any changes may continue for a long time after stopping of work. Although the average changes were small in the present study, they need not be trivial as some subjects may be more sensitive than others and because the accelerated decline in lung function may continue for many years, eventually adding up to a significant impact on health in some workers. We therefore suggest that airway obstructive changes, regardless of the presence of silicosis, are considered in the deliberations of TLV values and that both the active and the retired population of workers exposed to silica are included in the evaluation of the impact of silica dust. The present study does not provide sufficient information to judge whether or not the present TLV can be considered to be without impact on health, but the margin, if any, seems to be low.

The project was supported by the Swedish Work Environment Fund projects ASF 75/171, ASF79114, ASF80-304, and AMFO 870301 and the Swedish National Association against Chest and Heart Diseases. The chest radiographs were read by Dr G Hillerdal, C Åkesson assisted in the spiro- metric measurements and data for assessment of exposure were provided by $\mathrm{K}$ Bodén, $\mathrm{J}$ Kjellgren, and the labour inspectonates of Uppsala and Stockholm, who are gratefully acknowledged.

Requests for reprints to: Per Malmberg, Respiratory division, National Institute of Occupational Health, S- 17184 Solna, Sweden.

1 Davis GS. Pathogenesis of silicosis: current concepts and hypotheses. Lung 1986;164:139-54.

$2 \mathrm{Ng}$ T-P, Chan S-L, Lam K-P. Radiological progression and lung function in silicosis: a ten year follow up study. $B M \mathcal{F}$ 1987;295:164-8.

3 Barthel E. Dynamics of the loss of pulmonary function in patients with silicosis - a retrospective analysis by experts. Pneumologie 1990;44:883-6. (In German).

4 Cowie RL, Mabena SK. Silicosis, chronic airflow limitation, and chronic bronchitis in South African gold miners :see comments. Am Rev Respir Dis 1991;143:80-4.

5 Gross KB, White HJ, Smiler KL. Functional and morphologic changes in the lungs after a single intratracheal instillation of silica. Am Rev Respir Dis 1984;129:833-9.

6 Wright JL, Harrison N, Wiggs B, Churg A. Quartz but not iron oxide causes air-flow obstruction, emphysema, and small airways lesions in the rat. Am Rev Respir Dis 1988;138:129-35.

7 Kinsella M, Müller N, Vedal S, Staples C, Abboud RT, ChanYeung M. Emphysema in silicosis. A comparison of smokers with nonsmokers using pulmonary function testing and computed tomography. Am Rev Respir Dis 1990;141: $1497-500$.

8 Hnizdo E, Baskind E, Sluis CG. Combined effect of silica dust exposure and tobacco smoking on the prevalence of respiratory impairments among gold miners. Scand $\mathcal{f}$ Work Environ Health 1990;16:411-22.

9 Fridriksson HV, Hendenström H, Malmberg P, Hillerdal G. Early respiratory function changes in granite workers with normal chestradiographs as compared with workers with silicosis. In: Fridriksson, HV. Early changes in respiratory function caused by occupational dust or tobacco smoking Uppsala: thesis, Uppsala University, 1980.

10 American Thoracic Society. Standardization of spirometry1987 update. Am Rev Respir Dis 1987;136:1285-98.

11 Öhman $\mathrm{H}$. Prevention of silica exposure and elimination of silicosis. Am Ind Hyg Assoc F 1978;39:847-59.

12 Hedenström H, Malmberg, P, Fridriksson H. Reference values for lung function tests in men. Regression equations with smoking variables. Ups F Med Sci 1986;91:299-310.

13 Fridriksson HV, Malmberg P, Hedenström H, Hillerdal G. Reference values for respiratory function tests in males. Prediction formulas with tobaccosmoking parameters. Clin Physiol 1981;1:349-64.

Accepted 19 October 1992 